\title{
Design and Functioning of Automated Medicine Dispensing Module
}

\author{
Kunal Agrawal, Jil Jain, Vrutant Shah, Gargi Chauhan, Piyush Surani
}

\begin{abstract}
In a world where technology has bridged the gap between people communicating to reducing human efforts and improving efficiency, the problem that major hospitals \& pharmacies face is i.e. lack of staff \& resources. As per the survey conducted by LANCET ${ }^{[1]}$, India faces a significant shortage in medical staff which leads to patients being unattended for several hours. This problem can be solved if the tasks per staff member is reduced and one such way is by reducing their repetitive movement from the patient's room to the pharmacy for giving the medicines to the patient. This effort can be reduced by creating a remotely located machine which can be placed at the right place to dispense medicines automatically. This reduces the extra movements and hence provides them the time to do tasks that are of more importance. Although the concept of an automated medicine dispensing unit is not new, it is something that if built and implemented, can provide aid to patients in developing countries.
\end{abstract}

Keywords: Height Adjustment Part, Hopper mechanism, Medicinal Data Analysis, Medicine Dispensing Module, Spring Slider Mechanism.

\section{INTRODUCTION}

$T_{\text {his project was aimed to build a machine which }}$ provides medicinal aid to patients in a hospital. Upon observing and understanding the current progress in the field of pharmacy automation and going through past researches, the objectives were set to create a user friendly, compact \& ease-to-use automated dispensing unit for medicines. The Machine includes loading/unloading mechanism \& hopper mechanism for dispensing of medicines which includes sensors, servo motors, motor drivers, \& Raspberry Pi 3 which help in keeping track of medicines being dispensed. The entire operation of this machine will be done automatically once the medicines are loaded and after being dispensed, the medicines will be packaged in a sanitized way which will help in reducing the unnecessary crowd around pharmacy

Manuscript received on April 1, 2021.

Revised Manuscript received on April 9, 2021.

Manuscript published on April 30, 2021.

* Correspondence Author

Kunal Agarwal*, Mechanical Engineering, Indus University, Ahmedabad, India. Email: agarwalkunal.17.me@iite.indusuni.ac.in

Jil Jain, Mechanical Engineering, Indus University, Ahmedabad, India. Email: jainjil.17.me@iite.indusuni.ac.in

Vrutant Shah, Mechanical Engineering, Indus University, Ahmedabad, India. Email: shahvrutant.17.me@iite.indusuni.ac.in

Gargi Chauhan, Mechanical Engineering, Indus University, Ahmedabad, India. Email: gargichauhan.17.me@iite.indusuni.ac.in

Piyush Surani, Mechanical Engineering, Indus University, Ahmedabad, India. Email: piyushsurani.me@indusuni.ac.in

(c) The Authors. Published by Blue Eyes Intelligence Engineering and Sciences Publication (BEIESP). This is an open access article under the CC BY-NC-ND license (http://creativecommons.org/licenses/by-nc-nd/4.0/) store and also help in maintaining sanitary standards.

\section{RESEARCH AND DATA COLLECTED}

For starting the project, medicinal data of 109 commonly used medicines was collected and analyzed as shown in the Table 1 . The medicines were chosen as per the suggestion of doctors and pharmacists. The various shapes of medicines helped in building the dispensing module for universal height based medicines. Upon drawing inferences from the data collected, the project was initiated by analyzing past research papers and identified that focus was kept on the electronics part of the machine and not on the mechanical aspect. The medicinal data was bifurcated in terms of different standards shapes as follows: Cube, Oval (With height present $\&$ absent- This indicates the pills which are spherical or have minimal height), Cylindrical \& Round.

Table -1: Medicinal Data

\begin{tabular}{|c|c|c|c|c|c|c|c|}
\hline \multicolumn{8}{|c|}{ CUBE } \\
\hline $\begin{array}{l}\text { Max } \\
\text { Length }\end{array}$ & $\begin{array}{c}21.2 \mathrm{~m} \\
\mathrm{~m}\end{array}$ & $\begin{array}{c}\text { Min } \\
\text { Length }\end{array}$ & $\begin{array}{c}11.2 \mathrm{~m} \\
\mathrm{~m}\end{array}$ & $\begin{array}{l}\text { Comm } \\
\text { on } \\
\text { Range } \\
\text { Length }\end{array}$ & $17-18 \mathrm{~mm}$ & \multirow{4}{*}{$\underset{k}{\text { Remar }}$} & \multirow{4}{*}{$\begin{array}{c}\text { Every } \\
\text { size of } \\
\text { medicin } \\
\mathrm{e} \text { is } \\
\text { present } \\
\text { betwee } \\
\mathrm{n} \\
\text { commo } \\
\mathrm{n} \\
\text { length, } \\
\text { breath } \\
\text { and } \\
\text { height. }\end{array}$} \\
\hline $\begin{array}{l}\text { Max } \\
\text { Breath }\end{array}$ & $10 \mathrm{~mm}$ & $\begin{array}{l}\text { Min } \\
\text { Breath }\end{array}$ & $6.6 \mathrm{~mm}$ & $\begin{array}{l}\text { Comm } \\
\text { on } \\
\text { Range } \\
\text { Breath }\end{array}$ & $8-10 \mathrm{~mm}$ & & \\
\hline $\begin{array}{c}\text { Max } \\
\text { height }\end{array}$ & $9 \mathrm{~mm}$ & $\begin{array}{l}\text { Min } \\
\text { Height }\end{array}$ & $4.9 \mathrm{~mm}$ & $\begin{array}{l}\text { Comm } \\
\text { on } \\
\text { Range } \\
\text { Height }\end{array}$ & $5-6 \mathrm{~mm}$ & & \\
\hline $\begin{array}{l}\text { Averag } \\
\text { e } \\
\text { Length }\end{array}$ & $\begin{array}{c}17.48 m \\
m\end{array}$ & $\begin{array}{c}\text { Averag } \\
\mathrm{e} \\
\text { Breath }\end{array}$ & $\begin{array}{c}8.43 m \\
m\end{array}$ & $\begin{array}{c}\text { Averag } \\
\text { e } \\
\text { Height }\end{array}$ & $7.61 \mathrm{~mm}$ & & \\
\hline \multicolumn{5}{|c|}{ Total Number of Medicine } & \multicolumn{3}{|c|}{39 (35.77\%) } \\
\hline \multicolumn{8}{|c|}{ OVAL(HEIGHT PRESENT) } \\
\hline $\begin{array}{l}\text { Max } \\
\text { Length }\end{array}$ & $\begin{array}{c}14.6 \mathrm{~m} \\
\mathrm{~m}\end{array}$ & $\begin{array}{l}\text { Min } \\
\text { Length }\end{array}$ & $\begin{array}{c}11.3 \mathrm{~m} \\
\mathrm{~m}\end{array}$ & $\begin{array}{l}\text { Comm } \\
\text { on } \\
\text { Range } \\
\text { Length }\end{array}$ & $\begin{array}{c}14.3-14.6 \\
\mathrm{~mm}\end{array}$ & \multirow{3}{*}{$\underset{k}{\text { Remar }}$} & \multirow{3}{*}{$\begin{array}{c}3 \\
\text { medicin } \\
\text { e are } \\
\text { present } \\
\text { in } \\
\text { commo } \\
n \\
\text { Range } \\
\text { Length. } \\
\text { All four } \\
\text { medicin } \\
\text { e are of }\end{array}$} \\
\hline $\begin{array}{l}\text { Max } \\
\text { Breath }\end{array}$ & $\begin{array}{c}11.6 \mathrm{~m} \\
\mathrm{~m}\end{array}$ & $\begin{array}{l}\text { Min } \\
\text { Breath }\end{array}$ & $7 \mathrm{~mm}$ & $\begin{array}{l}\text { Comm } \\
\text { on } \\
\text { Range } \\
\text { Breath }\end{array}$ & N/A & & \\
\hline $\begin{array}{l}\text { Max } \\
\text { height }\end{array}$ & $7 \mathrm{~mm}$ & $\begin{array}{l}\text { Min } \\
\text { Height }\end{array}$ & $3.8 \mathrm{~mm}$ & $\begin{array}{l}\text { Comm } \\
\text { on } \\
\text { Range } \\
\text { Height }\end{array}$ & $5-5.2 \mathrm{~mm}$ & & \\
\hline
\end{tabular}

Published By: 


\section{Design and Functioning of Automated Medicine Dispensing Module}

\begin{tabular}{|c|c|c|c|c|c|c|c|}
\hline $\begin{array}{c}\text { Averag } \\
e \\
\text { Length }\end{array}$ & $\begin{array}{c}13.65 \mathrm{~m} \\
\mathrm{~m}\end{array}$ & $\begin{array}{c}\text { Averag } \\
\text { e } \\
\text { Breath }\end{array}$ & $\begin{array}{c}31.02 \mathrm{~m} \\
\mathrm{~m}\end{array}$ & $\begin{array}{c}\text { Averag } \\
e \\
\text { Height }\end{array}$ & $5.25 \mathrm{~mm}$ & & \begin{tabular}{|c} 
differen \\
$\mathrm{t}$ \\
Breath. \\
2 \\
medicin \\
e are \\
present \\
in \\
Comm \\
on \\
Range \\
Height.
\end{tabular} \\
\hline \multicolumn{5}{|c|}{ Total Number of Medicine } & \multicolumn{3}{|c|}{$5(4.58 \%)$} \\
\hline \multicolumn{8}{|c|}{ OVAL(HEIGHT ABSENT) } \\
\hline $\begin{array}{l}\text { Max } \\
\text { Diamet } \\
\text { er }\end{array}$ & $\begin{array}{c}10.4 \mathrm{~m} \\
\mathrm{~m}\end{array}$ & $\begin{array}{c}\text { Min } \\
\text { Diamet } \\
\text { er }\end{array}$ & $7 \mathrm{~mm}$ & $\begin{array}{l}\text { Comm } \\
\text { on } \\
\text { Range } \\
\text { Diamet } \\
\text { er }\end{array}$ & N/A & & \multirow{3}{*}{\begin{tabular}{|l} 
All 5 \\
medicin \\
e are of \\
differen \\
$\quad t$ \\
Diamet \\
er and \\
| Length.
\end{tabular}} \\
\hline $\begin{array}{c}\text { Max } \\
\text { Length }\end{array}$ & $22 \mathrm{~mm}$ & $\begin{array}{c}\text { Min } \\
\text { Length }\end{array}$ & $\begin{array}{c}12.6 \mathrm{~m} \\
\mathrm{~m}\end{array}$ & $\begin{array}{l}\text { Comm } \\
\text { on } \\
\text { Range } \\
\text { Length }\end{array}$ & N/A & $\underset{k}{R e m a r}$ & \\
\hline $\begin{array}{c}\text { Averag } \\
\text { e } \\
\text { Diamet } \\
\text { er }\end{array}$ & $\begin{array}{c}9.86 \mathrm{~m} \\
\mathrm{~m}\end{array}$ & $\begin{array}{c}\text { Averag } \\
\text { e } \\
\text { Height }\end{array}$ & $\begin{array}{c}13.96 \mathrm{~m} \\
\mathrm{~m}\end{array}$ & \multicolumn{3}{|c|}{ N/A } & \\
\hline \multicolumn{5}{|c|}{ Total Number of Medicine } & \multicolumn{3}{|c|}{$5(4.58 \%)$} \\
\hline \multicolumn{8}{|c|}{ CYLINDRICAL } \\
\hline $\begin{array}{l}\text { Max } \\
\text { Diamet } \\
\text { er }\end{array}$ & $7.4 \mathrm{~mm}$ & $\begin{array}{l}\text { Min } \\
\text { Diamet } \\
\text { er }\end{array}$ & $5.9 \mathrm{~mm}$ & $\begin{array}{c}\text { Comm } \\
\text { on } \\
\text { Range } \\
\text { Diamet } \\
\text { er }\end{array}$ & $6 \mathrm{~mm}$ & & $\begin{array}{c}6 \mathrm{~mm} \\
\text { Diamet } \\
\text { er } \\
\text { medicin } \\
\text { e is }\end{array}$ \\
\hline $\begin{array}{l}\text { Max } \\
\text { Height }\end{array}$ & $21 \mathrm{~mm}$ & $\begin{array}{l}\text { Min } \\
\text { Height }\end{array}$ & $17 \mathrm{~mm}$ & $\begin{array}{l}\text { Comm } \\
\text { on } \\
\text { Range } \\
\text { Height }\end{array}$ & $\underset{\mathrm{m}}{17-17.5 \mathrm{~m}}$ & $\underset{\mathbf{k}}{\text { Remar }}$ & $\begin{array}{c}\text { most } \\
\text { commo } \\
\mathrm{n} \text { as } 4 \\
\text { medicin }\end{array}$ \\
\hline $\begin{array}{l}\text { Averag } \\
\text { e } \\
\text { Diamet } \\
\text { er }\end{array}$ & $6.2 \mathrm{~mm}$ & $\begin{array}{c}\text { Averag } \\
\text { e } \\
\text { Height }\end{array}$ & $\begin{array}{c}17.87 \mathrm{~m} \\
\mathrm{~m}\end{array}$ & & N/A & & \begin{tabular}{|c} 
e are \\
present \\
out of \\
9.
\end{tabular} \\
\hline \multicolumn{5}{|c|}{ Total Number of Medicine } & \multicolumn{3}{|c|}{$9(8.25 \%)$} \\
\hline \multicolumn{8}{|c|}{ ROUND } \\
\hline $\begin{array}{l}\text { Max } \\
\text { Diamet } \\
\text { er }\end{array}$ & $\begin{array}{c}14.9 \mathrm{~m} \\
\mathrm{~m}\end{array}$ & $\begin{array}{c}\text { Min } \\
\text { Diamet } \\
\text { er }\end{array}$ & $5 \mathrm{~mm}$ & $\begin{array}{c}\text { Comm } \\
\text { on } \\
\text { Range } \\
\text { Diamet } \\
\text { er } \\
\end{array}$ & $\begin{array}{c}12-12.9 \mathrm{~m} \\
\mathrm{~m} \\
7-7.7 \mathrm{~mm} \\
9.2-9.8 \mathrm{~mm}\end{array}$ & \multirow{3}{*}{$\underset{\mathbf{k}}{\operatorname{Remar}}$} & \multirow{3}{*}{$\begin{array}{c}\text { Most of } \\
\text { the } \\
\text { medicin } \\
\text { e are } \\
\text { present } \\
\text { in } \\
\text { Comm } \\
\text { on } \\
\text { Range } \\
\text { Diamet } \\
\text { er as } \\
\text { well as } \\
\text { in } \\
\text { Comm } \\
\text { on } \\
\text { Range } \\
\text { Height. }\end{array}$} \\
\hline $\begin{array}{l}\text { Max } \\
\text { Height }\end{array}$ & $6.3 \mathrm{~mm}$ & $\begin{array}{l}\text { Min } \\
\text { Height }\end{array}$ & $2.2 \mathrm{~mm}$ & $\begin{array}{l}\text { Comm } \\
\text { on } \\
\text { Range } \\
\text { Height } \\
\end{array}$ & $3-4.8 \mathrm{~mm}$ & & \\
\hline $\begin{array}{l}\text { Averag } \\
\text { e } \\
\text { Diamet } \\
\text { er }\end{array}$ & $\begin{array}{c}7.52 \mathrm{~m} \\
\mathrm{~m}\end{array}$ & $\begin{array}{c}\text { Averag } \\
\mathrm{e} \\
\text { Height }\end{array}$ & $\begin{array}{c}1.86 \mathrm{~m} \\
\mathrm{~m}\end{array}$ & & N/A & & \\
\hline \multicolumn{5}{|c|}{ Total Number of Medicine } & \multicolumn{3}{|c|}{$51(46.78 \%)$} \\
\hline
\end{tabular}

\section{DESIGN AND FUNCTIONING OF MEDICINE DISPENSING MODULE}

The key to this project is the development of the Dispensing Module. The Module has 3 major components: The body, slider-spring mechanism and height adjustment part. The medicines are inputted manually into the storage chamber from the top lid. Based on the height of the medicine, the height is adjusted and the adjustment part is locked. Once the medicines are stored, the medicine that is placed in the slot at the bottom of the module is displaced towards the opening at the bottom by the slider spring mechanism which is controlled by a motor. The built prototype is shown in figures $1 \& 2$ along with detailed cross sectional modules shown in figure 3. A detailed part description of figure 3 is explained as follows:

1-Storage Chamber Opening: Opening to input medicines into the module.

2-Medicine

3-Storage Chamber: Space to store medicines under suitable storage conditions and providing isolation around the chamber.

4-Medicine Slot: Slot where medicines will fall under gravity and be placed for further dispensing.

5-Motor Attachment Slot: Space for adding extension slit which will provide sliding motion to the slider.

6-Slider: Part which moves sideways to shift medicine from Medicine slot to exit slot.

7-Exit Slot: Slot through which medicine will be dispensed out of the module.

8-Spring: Spring adds a balancing part for smooth movement of slider.

9-Hight Adjustment Part: Part used for adjusting size of module as per the height of medicine.
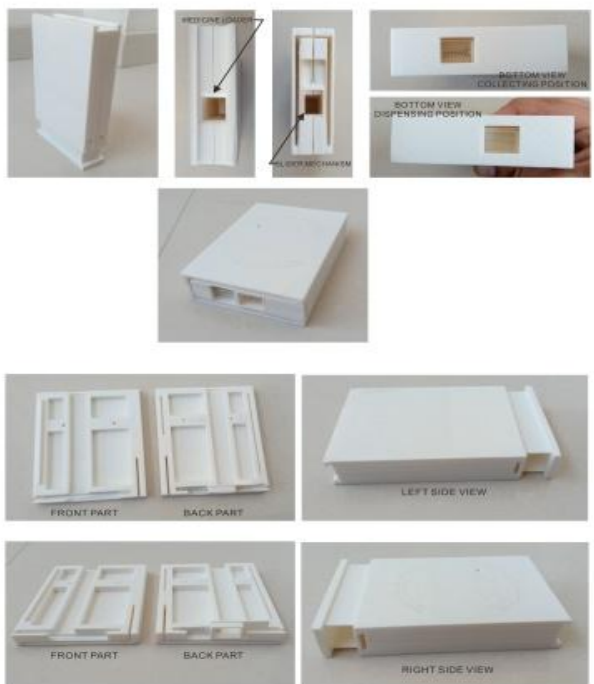

Fig.1: Images of Prototype

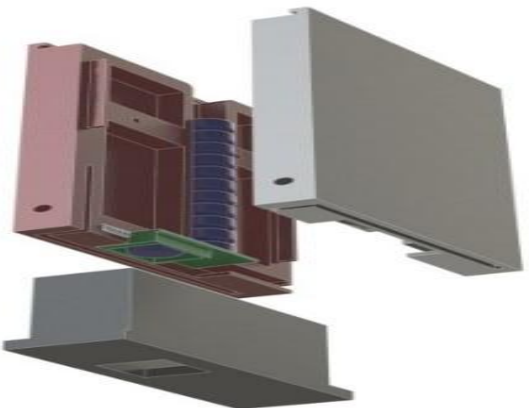

Fig. 2: Exploded view of Design

Published By:

Blue Eyes Intelligence Engineering

\& Sciences Publication

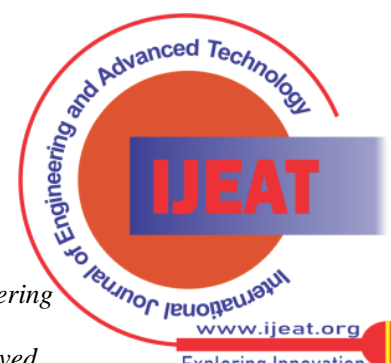




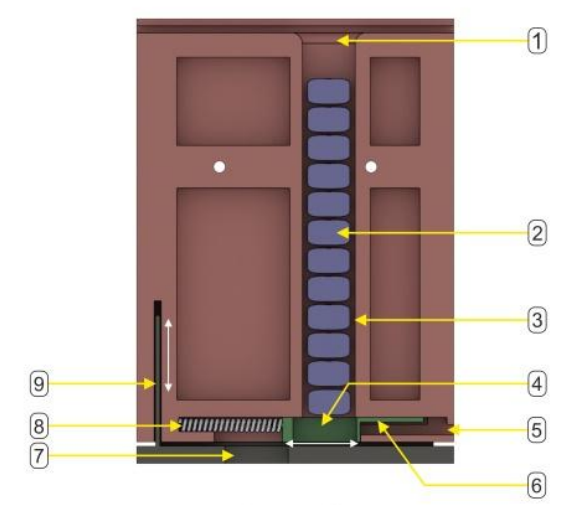

Fig. 3: Cross-section of Design

\section{FLOW OF OPERATIONS}

The Machine is given input of prescribed medicines by a doctor via a computer interface and the signal is sent to a microcontroller which verifies the availability of medicines in the Dispensing module and upon verification, a signal is sent to the motor driver connected to the motors which are attached to the dispensing module for dispensing medicines as per the prescription. While being dispensed, the medicines are counted using sensors and upon reaching the counter as per the prescription, the motor stops movement and dispensing of medicines is halted. Post dispensing of medicines, they are packaged in cylindrical vials placed at the exit end of the machine and the vials are later collected by the user. The flow of operations is explained using Flowchart 1. Flow of Operations:

Step 1: User inputs data through computer

Step 2: Input is sent to the Microcontroller where it is verified with Medicine Data in dispenser

Step 3: Post verification, signal is sent to Dispensing Module for initiating the process.

Step 4: The signal is further sent to Motor Driver which actuates the motor which in turn moves the slider to dispense medicine.

Step 5: The medicines keep dispensing until the counter reaches its limit.

Step 6: Lastly the medicine is packaged and received by the user

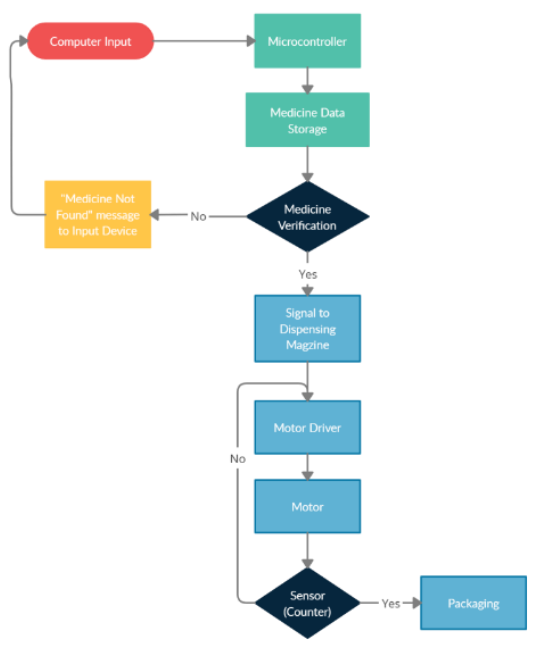

Flowchart 1: Flow of Operations

\section{HARDWARE COMPONENTS}

\begin{tabular}{|c|c|}
\hline Component & Use \\
\hline Servo Motors & $\begin{array}{c}\text { Used in providing motion to Slider-Spring } \\
\text { Mechanism. These are attached with a slit } \\
\text { which is connected to the slider. }\end{array}$ \\
\hline Motor Drivers & $\begin{array}{c}\text { Motor Drivers receive signal from } \\
\text { microcontroller to dispense medicines by } \\
\text { movement of the motor which in turn } \\
\text { moves the slider. }\end{array}$ \\
\hline $\begin{array}{c}\text { Object } \\
\text { Setection } \\
\text { Medicine }\end{array}$ & $\begin{array}{c}\text { Used for counting medicines coming out } \\
\text { of expensing } \\
\text { Module }\end{array}$ \\
\hline $\begin{array}{c}\text { Raspberry Pi 3 } \\
\text { medicines. }\end{array}$ \\
\hline Used for handling operation of entire \\
machine.
\end{tabular}

\section{RESULT AND DISCUSSION}

The design of module was completed and prototypes prepared were well functioning. The Machine successfully dispenses medicines of varying height using a similar module. the slider-spring mechanism provided a good alternative to drop mechanism and helped in keeping a count of medicines being dispensed, also ensuring that medicines flow without getting stuck in storage space. Overall the machine worked as expected and provided insights for improvement.

\section{CONCLUSION}

The project design and implementation lead to find solution for automating processes in pharmacies and providing prescribed medicines to patients automatically. The medicine dispensing module solves the problem of storing and dispensing of medicines of different heights and on implementing, the machine will provide aid to patients and medical staff in a hospital.

Future Scope:

The machine can be modified to become storage and dispensing unit for injections and can improve pharmacy automation.

\section{REFERENCES}

1. Lancet Article India: Towards Universal Health Coverage Volume 377, Issue 9765, P587-598, Februray 12, 2011

2. M Sangeetha, T V Janardhanarao, Ch S Rama Gowri, AUTOMATIC MEDICINE VENDING SYSTEM-MEDICAL ATM ISSN 2455-2631@ October 2016 IJSDR | Volume 1, Issue 10 IJSDR1610031 International Journal of Scientific Development and Research (IJSDR)

3. Sarika Oundhakar, Automatic Medicine Vending Machine, India International Journal of Engineering Technology Science and Research IJETSR ISSN 2394 - 3386 Volume 4, Issue 12 December 2017

4. Abhishek Singh, TOUCH SCREEN BASED AUTOMATIC MEDICAL VENDING MACHINE, IJIRST -International Journal for Innovative Research in Science \& Technology| Volume 1 | Issue 11 April 2015 ISSN (online): 2349-6010.

5. Shrikant Bhange, Kaveri Niphade, Tejshri Pachorkar, Akshay Pansare, Automated Vending Machine, International Journal of Advanced Research in Electronics and Communication Engineering (IJARECE) Volume 4, Issue 3, March 2015. 


\section{Design and Functioning of Automated Medicine Dispensing Module}

6. Shraddha Kadam, Aishwarya Kale, Punam Nimase, Sheela Padwal, Shobhit Khandare, AUTOMATED MEDICINE DISPENSING MACHINE, International Journal of Technical Research and Applications e-ISSN: 2320-8163, www.ijtra.com Volume 4, Issue 3 (May-June, 2016), PP. 73-76

\section{AUTHORS PROFILE}

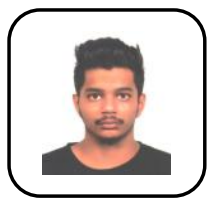

Kunal Agarwal, is a B.Tech student of Mechanical Engineering Department of Indus University of Technology, Ahmedabad, Gujarat. He has prominently participated in departmental workshops, non-technical events and been an eager student who seeks knowledge about the basic functioning of different mechanical machines. He was also been part of college's event management committee and elected as Technical Head in Indus Mechanical Engineering Association (IMEA) in 2019-21.

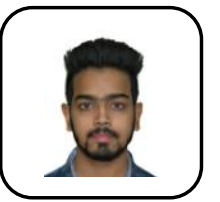

Jil Jain, is a B.Tech student of Mechanical Engineering Department of the Indus University of Technology, Ahmedabad, Gujarat. The unique quality of his is a tendency to go beyond the syllabus. As an example of it, he prominently participated in numerous technical events, workshops during his bachelor's study. He demonstrated great perseverance and initiative in co-curricular activities also. He has been part of the college's event management committee and elected as a designer head in Indus Mechanical Engineering Association.

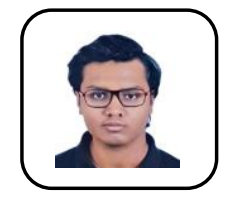

Vrutant Shah, is a B.Tech student of Mechanical Engineering Department of Indus University of Technology, Ahmedabad, Gujarat. During the four years of his course, he has prominently participated in Technical fests, departmental workshops and been an eager student who seeks knowledge about the basic functioning of different mechanical machines. He was Creative Head in Indus Mechanical Engineering Association (IMEA).

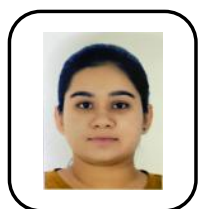

Gargi Chauhan, is a B.Tech student of Mechanical Engineering Department of Indus University Ahmedabad, Gujarat. She has participated in theoretical as well as practical sessions with an equal fervour and have enhanced her knowledge in machine optimization and product designing. She has attended several workshops and participated in co-curricular activities. She was also a part of International Student program held at Carleton University in 2019.

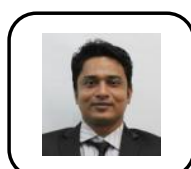

Piyush Surani, has completed Bachelors of Engineering in Mechanical Engineering and Masters of Engineering in Computer Aided Design And Manufacturing. He is currently Assistant Professor in Indus University, Ahmedabad, Gujarat. He has published 5 research paper

in reputed journals.

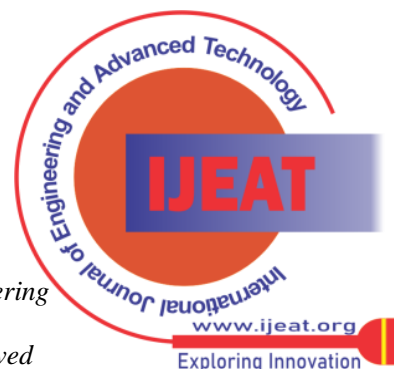

